\title{
Tests of loading efficiency of worm-type cutting drums in longitudinally inclined longwall working
}

\begin{abstract}
This article presents the execution and results of tests of the loading efficiency of wormtype cutting drums as a function of the slope of a longwall working. The tests were carried out at various angles of longitudinal inclination of a longwall within a range of $0^{\circ}$ to $9^{\circ}$ along the strike. In real conditions, the separation of the two basic processes that take place during operation of a longwall shearer (i.e., milling and loading) is not possible; therefore, the research was carried out under laboratory conditions at the Department of Mining, Dressing, and Transport Machines at AGH University of Science and Technology in Krakow. The tests were carried out on a special station that allowed for the gradual change of the longitudinal and transverse slope of a longwall working. Based on the conducted tests, it was found that the inclination of a longwall working influences the loading efficiency; i.e., that, along with an increase in the angle of the longitudinal inclination, loading resistance increases while the loading efficiency decreases.
\end{abstract}

Key words: laboratory tests, spoil loading, worm-type cutting drums

\section{INTRODUCTION}

Hard coal mining in most European countries (including Poland) is practically carried out by longwall methods (in particular by longwall shearers). The longwall system has many advantages, which include low operational losses, a small amount of preparatory work, a reduction of the risk of rock bursts (due to the convenient stress distribution in the rock mass), a reduction in the risk of fires due to the clean bed selection, and the possibility of ventilation by means of a circulating air current [1]. However, each longwall working is characterized by individual hazards and difficulties in coal mining. Such threats include the so-called co-existing hazards: fire, rock burst, temperature, and methane [1]. Meanwhile, the technical difficulties certainly include walls with heights of less than $1.5 \mathrm{~m}$ and a slope in the excavation (the dip angle of the seam). As in the case of determining the height ranges of walls in particular categories, the slope of the seam is also a matter of convention. The most frequent divisions are as follows [2, 3]:

- horizontal $<5^{\circ}$,

- almost horizontal 5-15,

- slightly inclined $15-30^{\circ}$,

- strongly inclined $30-45^{\circ}$,

- steep $>45^{\circ}$.

Bearing in mind the heading longwall excavations, their direction in reference to the slope of the seam, and the direction of the exploitation, we can distinguish between longitudinal and transverse wall slopes. If the face of the wall moves perpendicularly to the inclination of the seam (Fig. 1), such a wall is called a longitudinal wall. However, when the face of the wall moves in a parallel fashion along the strike or dip to the inclination of the seam, such a wall is referred to as a transverse wall (Fig. 2) [4].

In mining practice, excavation in the case of inclined seams is oriented in such a way that the 
transverse inclination angle of the wall is as small as possible, permitting higher values of longitudinal inclination (even $45^{\circ}$ ). This is mainly due to the operational capabilities of the machines and devices working in the wall [4]. An example of longwall shearers working at a large longitudinal inclination are Beijing HOT Mining Tech shearers (Fig. 3) [5, 6].

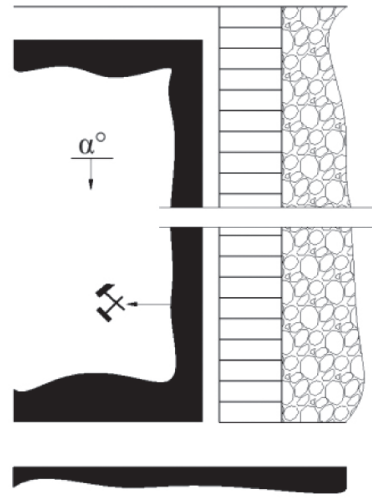

Fig. 1. Longitudinally inclined wall

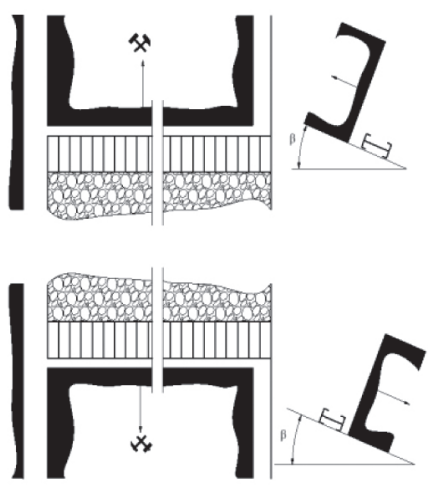

Fig. 2. Transversely inclined wall

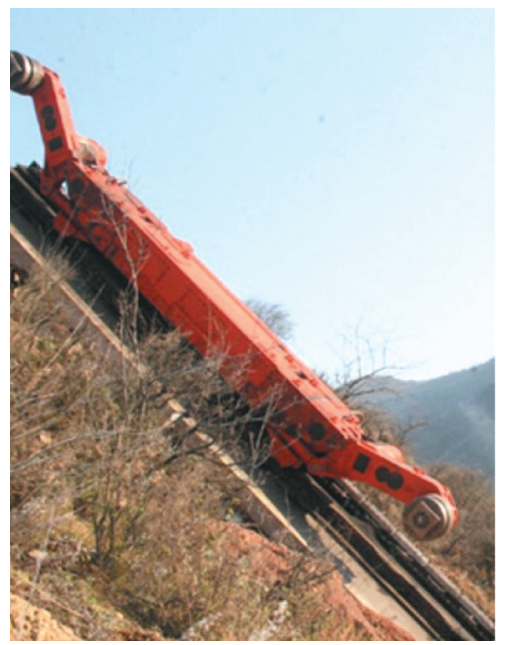

Fig. 3. Classic longwall shearer for strongly inclined seams at testing grounds of Beijing HOT Mining Tech [5]
As can be seen from the literature, the ranges of the permissible slopes for mechanized longwall systems is up to $45^{\circ}$ longitudinally and up to $\pm 20^{\circ}$ transversely. It should be noted that the best results are obtained by mechanized walls in horizontal or slightly inclined seams; as the inclination increases, the efficiency of the walls decreases significantly [6].

Therefore, given the above literature-derived data, it was checked to what extent the angle of inclination of a longitudinal longwall working influences the loading process of worm-type cutting drums, thus to obtain the efficiency of this process.

The loading process is crucial, as there is a need for the continuous transport of the spoil produced in the mining process onto the longwall conveyor. The cleaning of the shearer path enables the shearer to be moved to a new field by a full swath. Leaving the spoil on the shearer path can lead to the so-called loss of swath; i.e., moving the conveyor by a swath smaller than assumed (required). This situation affects the fact that the drums cannot work across the entire width, which results in the failure to achieve the target daily production. The second undesirable effect is the so-called elevation of the conveyor, consisting of lifting it on the remaining spoil. This can cause difficulties in continuing the shearer's operation at the height assumed for a given wall. In addition, this may lead to a reduction in the durability of the picks due to the fact that the cutting heads cut into the roof rocks [7].

\section{AIM AND FOUNDATION OF RESEARCH}

The purpose of the research was to determine the influence of the longitudinal angle of a longwall working on the loading efficiency. As we find in the literature [3], the maximum longitudinal slope of medium walls can be $35^{\circ}$, while a transverse slope can range up to $20^{\circ}$ along the strike and $15^{\circ}$ along the dip. Therefore, the angle values selected for the tests will be representative of nearly horizontal walls. The tests were carried out for four angles of inclination of the excavation. As these are pilot studies on the topic, the lowest values of inclination angles were tested; first for a horizontal excavation with an angle of $0^{\circ}$, then three longitudinal inclination angles: $3^{\circ}, 6^{\circ}, 9^{\circ}$. Also, the station at which the loading efficiency measurements were carried out has the possibility of applying these angles during the tests. During the tests, the values of the fill factor of the drum $\left(k_{w}\right)$ and the 
coefficient of the loosening of the output spoil $\left(k_{r}\right)$ have been taken into account, which affect the efficiency of the loading. The ranges and values of these coefficients have been determined on the basis of empirical studies and are adopted within the limits of $k_{w}=0-1, k_{r}>1$, [8]. The analytical model of the process of loading using worm-type cutting drums has been adopted for the interpretation of the test results $[4,9]$. In accordance with the assumed objective of the study, it was assumed that the loading process will be separated from the milling process so that the study could focus only on the loading process. This assumption was possible to be included only under laboratory test conditions.

In connection with the above, the tests of the loading process were laboratory tests and were carried out at a specially prepared test station. The test station in question enables us to carry out the loading process as well as to use different angles of the longitudinal and transverse inclination of a longwall working. A specially designed worm-type cutting drum was used for the tests with a specific angle of the winding of the thread.

\section{RESEARCH PLAN AND METHODOLOGY}

The main assumption for testing the efficiency of a loading with worm-type cutting drums was to check to what extent the longitudinal slope of a longwall working impacts the quality (efficiency) of the loading process. The tests needed to be carried out in accordance with the dependencies defining the proper course of the loading process; i.e., that the internal volume of the drum $\left(V_{o}\right)$ is greater than the quantity of the spoil produced during the mining $\left(V_{u}\right)$ for one or two drums. These dependencies have been described in the literature [4] for the operation of drums with and without loaders. In the equations (described in the literature [4]), there are parameters such as the volumes of the front and rear drum, which can be described as follows:

- spoil volume for the front drum:

$$
V_{u p}=V_{u} \frac{D_{s} z v_{p} k_{r} k_{L}}{n}
$$

- spoil volume for the rear drum:

$$
V_{u t}=\frac{\left(H-D_{s}\right) z v_{p} k_{r} k_{L}}{n}
$$

where:

$V_{u}$ - mining efficiency of the drum $[\mathrm{Mg} / \mathrm{h}]$,

$D_{s}$ - diameter of the drum [m],

$H$ - height of the mined wall [m],

$Z$ - swath [m],

$k_{r}$ - loosening coefficient of the output spoil [-],

$k_{L}$ - coefficient defining the amount of spoil loaded with no participation of the drum [-],

$k_{w}-$ drum filling coefficient [-].

Due to the above, only one front drum was designated for the tests, because it always machines the face with its whole diameter. Coefficient $k L$ was adopted as equal to 1 ; this means that all of the spoil will be loaded using a worm-type cutting drum. From Relationship (1), it follows that:

$$
k_{w} \geq \frac{D_{s} \cdot z}{v_{o}} \cdot \frac{v_{p}}{n} \cdot k_{r}
$$

where:

$$
\begin{aligned}
& \frac{D_{S} \cdot z}{v_{o}}-\text { construction parameters of the drum, } \\
& \frac{v_{p}}{n}-\text { kinematic parameters. }
\end{aligned}
$$

From Formula (3), the construction parameters of the drum without the pick system required for the given conditions were determined.

For the needs of the laboratory tests, it was necessary to create a spoil with a previously assumed grain composition. The use of a spoil with a specific grain composition allowed for obtaining different values of spoil loosening coefficient $k_{r}$. For a given spoil and a given worm-type drum, the change of the feed speed and the rotational speed of the drum determines the value of the filling factor of the drum $k_{w}$.

The parameters measured in the tests will be as follows:

- power consumption of loading resistance $N p$ measured on the feed motor as a function of loading efficiency of the drum $\eta_{t}$,

- power consumption of loading resistance $N_{o}$ measured on the drum's engine as a function of loading efficiency of the drum $\eta_{t}$,

- loading efficiency of the drum $\eta_{t}$, measured as the cross-section of the spoil heap $[9,11]$.

The range of rotational speed $n$ and feed rate $v_{p}$ was determined based on the actual structural and kinematic parameters of the drum used for testing. 
Table 1

Values of drum fill factor $\boldsymbol{k}_{w}$ and spill loosening factor $\boldsymbol{k}_{\boldsymbol{r}}$

\begin{tabular}{|c|c|c|c|c|c|c|c|c|c|c|}
\hline \multirow{2}{*}{ No. } & \multirow{2}{*}{$\begin{array}{c}\text { Spoil } \\
\text { loosening } \\
\text { factor } \\
k_{r} \\
\text { (granulation) }\end{array}$} & \multirow{2}{*}{$\begin{array}{l}\text { Rotational } \\
\text { speed of } \\
\text { the drum } \\
n[\mathrm{rpm}]\end{array}$} & \multicolumn{8}{|c|}{$\begin{array}{c}\text { Feed speed } \\
v_{p}[\mathrm{~m} / \mathrm{min}]\end{array}$} \\
\hline & & & 1 & 2 & 3 & 4 & 5 & 6 & 7 & 8 \\
\hline 1 & \multirow{3}{*}{$\begin{array}{c}1.69 \\
(0-45 \mathrm{~mm})\end{array}$} & 40 & 0.322 & 0.644 & 0.967 & 1.289 & 1.611 & 1.933 & 2.256 & 2.578 \\
\hline 2 & & 80 & 0.161 & 0.322 & 0.483 & 0.644 & 0.806 & 0.967 & 1.128 & 1.289 \\
\hline 3 & & 120 & 0.107 & 0.215 & 0.322 & 0.430 & 0.537 & 0.644 & 0.752 & 0.859 \\
\hline
\end{tabular}

The values of these parameters are included in Table 1 and reflect the values of the parameters used under real conditions (rotational speed of the drum, feed rate). Dependence (3) was used to compile this table. The table illustrates the theoretical values of fill factor $k_{w}$ of the drum depending on feed speed $v_{p}$ and the rotational speed of organ $n$ for different spoil loosening coefficients $k_{r}$. This allows for the easy and quick selection of the feed and rotational speeds of the drum in order to obtain the fill factor required for the test.

The values presented in Table 1 allow us to carry out tests for three angles of longitudinal inclination of a longwall working; namely, $3^{\circ}, 6^{\circ}$, and $9^{\circ}$. On the basis of the tests and the results obtained, it will be possible to analyze and assess the influence of the angle of inclination of the excavation on the loading efficiency as a function of the rotational speed of the drum and feed rate, taking into account drum fill factor $k_{w}$ and spill loosening factor $k_{r}$.

a)

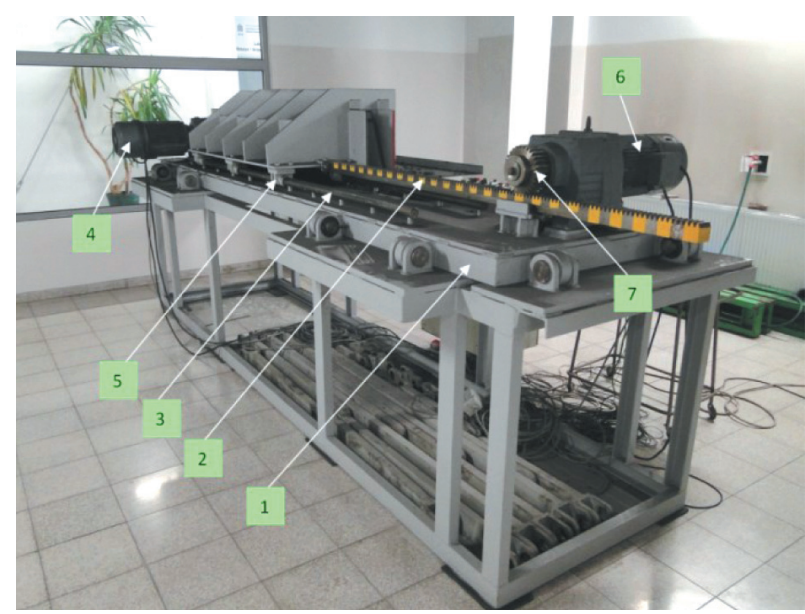

4. LABORATORY STATION FOR TESTING LOADING PROCESS USING WORM-TYPE CUTTING DRUMS

The laboratory station (Fig. 4a) intended for testing the loading process consists of a structural part and a measuring system. The structural part of the station is a sliding frame, with the body of the cutting drum mounted on it (Fig. 4b). The feed drive (toothed wheel and toothed rack) allows the frame to move along guide rails, thus realizing the movement of the drum during operation.

The feed drive motor allows for adjusting the linear speed of the frame. Two guide rails allow the frame to travel over a distance of $1200 \mathrm{~mm}$. The power supply system of the rotor enables the changing of directions and regulation of the rotational speed of the drum. The construction of the sliding frame makes it possible to place a heap of the loaded spoil between its sheets [3].

b)

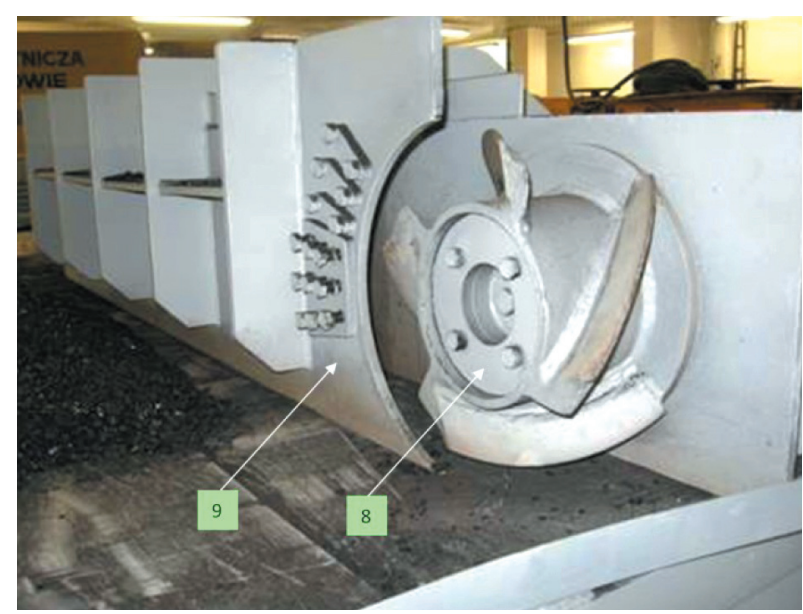

Fig. 4. Station for testing loading process: a) view of test bench from side of feed motor and rail; b) view from drum: 1 - station base, 2 - toothed rack, 3 - guide rails, 4 -drum drive motor, 5 - sliders, 6 - feed drive motor, 7 - gear cog, 
a)

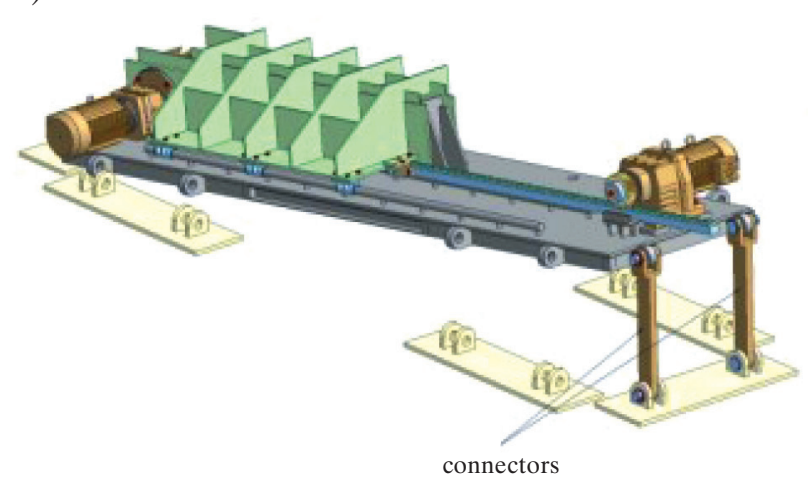

b)

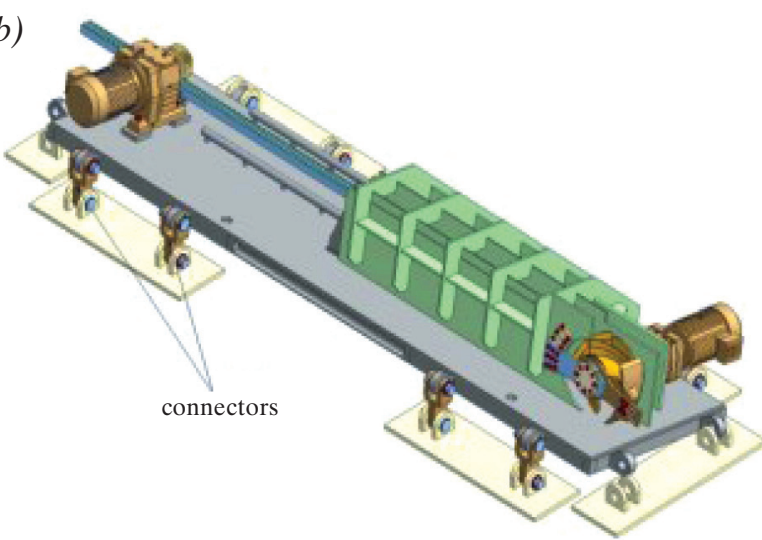

Fig. 5. Station for testing loading process: a) longitudinal inclination; b) transverse inclination

The station makes it possible to regulate the basic kinematic parameters of the station elements, such as:

- linear speed of the frame (feed speed),

- rotational speed of the drum,

- direction of the drum's rotation,

- feed direction (frame movement).

The position allows for setting the longitudinal and transverse inclination angle as shown in Figure 5. The inclination of the station can be achieved through connectors that have different lengths and correspond to the appropriate angles.

A quadruple-entry worm-type cutting drum with normal threads without a shielded loader was used for testing. The selection of the organ for the research was based on the professional literature and previous research, which was described in Item [10]. The drum in question is characterized by the following parameters:

- $Z_{U}=0.133 \mathrm{~m}$,

- $D=0.334 \mathrm{~m}$,

$-d=0.2 \mathrm{~m}$,

$-b=0.012 \mathrm{~m}$,

$-i=4$,

$-\alpha_{2}=28.33^{\circ}$,

$-k_{k p}=1$, where:

$Z_{U}$ - swath of the drum without the cutting disc (the mining-loading part) $[\mathrm{m}]$,

$D$ - diameter of the drum, including the loading extensions $[\mathrm{m}]$,

$d$ - drum's hub diameter [m],

$b$ - thickness of the thread [m],

$i$ - number of threads [-],

$\alpha_{2}-$ thread twist angle [ ${ }^{\circ}$ ],

$k_{k p}$ - coefficient taking into account the shape of the drum's hub, defined as the relationship between volume other than cylindrical to the volume of the hub cylin$\operatorname{der}(d)[-]$.

The measuring part of the station was a specially designed measuring system that allows for measuring and registering the power consumption of both engines.

The measuring system used on the test bench was equipped with current transformers, active power converters, a measurement module, and a measuring computer (Fig. 6).

Rotational speed measurement on the rotors (S) was carried out by the encoders (E), from which the signals were transmitted to the power box.

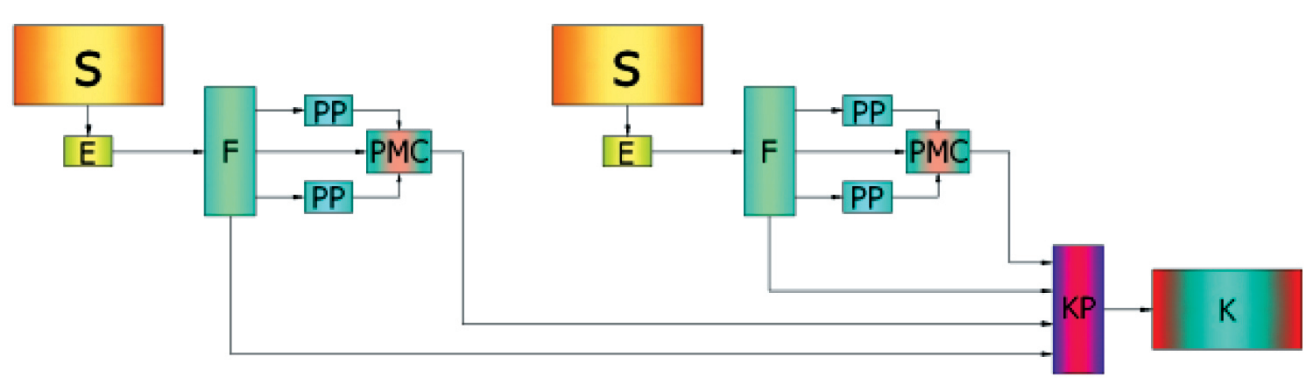

Fig. 6. Diagram of test bench measuring system [10] 
In the power box, the signal is transferred to the inverter $(\mathrm{F})$ and through the current transformers $(\mathrm{PP})$, active power converters (PMC), and measurement card (KP) (docking station) to the computer $(\mathrm{K})$ in which the data is saved.

\section{PRELIMINARY TESTS}

It was also assumed that the research will be twostaged; namely, it would consist of preliminary and primary tests. The initial tests were aimed at determining whether the measuring system works properly, whether the assumptions for testing are correct, and whether the necessary number of repetitions of the measurements are performed during the primary tests. In connection with the above, three measurements were taken for the constant rotation of the drum and feed speed. The results were analyzed statistically according to the Stein method [14]. Then, from the $t$-Student distribution, it was assumed that it is sufficient to perform two tests for each set of parameters.

Based on the preliminary research, a number of conclusions have been formulated. During the operation of the drum without a loader, no increase in power consumption was observed in any of the motors. However, it was observed that as the value of filling factor $k_{w}$ increases, the shape and position of the output spoil heap changes.

In connection with the above, it was assumed that the main criterion for assessing the loading process for the drum without a loader will only be its loading efficiency.

The efficiency of the loading was defined as the ratio of the cross-sectional area of the heap of the spoil loaded to the area of the total cross-section of the dislocated spoil [8]. Therefore, it was assumed that the cross-section of the heap will be illustrated by a triangle (Fig. 7), which would be determined by the following values: $a, b, h$. Through this, it would be possible to determine the loading efficiency for a given measurement. The $145 \mathrm{~mm}$ dimension visible in Figure 7 results from the swath of the cutting drum and is a delimitation between the loaded and unloaded spoil. The efficiency of loading $\xi_{t}$ was calculated in the same way for all samples; that is, as the quotient of the cross-sectional area of the spoil loaded $P_{t s i r d}$ and average cross-section area $P_{c \text { średnie }}$ of the total spoil multiplied by $100 \%$. To calculate the loading efficiency, the following dependence was used:

$$
\eta_{t}=\frac{P_{\text {tmean }}}{P_{\text {cmean }}} 100 \%
$$

\section{PRIMARY TESTS}

Coal from one of the Polish mines was used for the tests. The coal to be tested was selected in terms of its properties and granularity class for the test cutting drum.

The preparation of the spoil was carried out at the Accredited Laboratory for Research and Property of Stone Products at AGH University of Science and Technology. The aim of preparing the spoil was to isolate the fractions and determine the bulk density in the loose state. On the basis of the volume density of the coal grains (i.e., the density that coal has in the seam and the bulk density of its granulation), it was necessary to determine the so-called spoil looseness coefficient $k_{r}$. The volume density was determined in accordance with the PN-EN 1097-6 standard and the bulk density in accordance with the requirements of the PN-EN 1097-3: 2000 standard. While determining the $k_{r}$ coefficient, the geometrical parameters of the drum used for the tests were also taken into account [10]. The coal to be tested had a granulation of $0-45 \mathrm{~mm}$ and a looseness coefficient of $k_{r}=1.69$. The $k_{r}$ coefficient was assumed on the basis of the experimental studies and literature data [11-13].

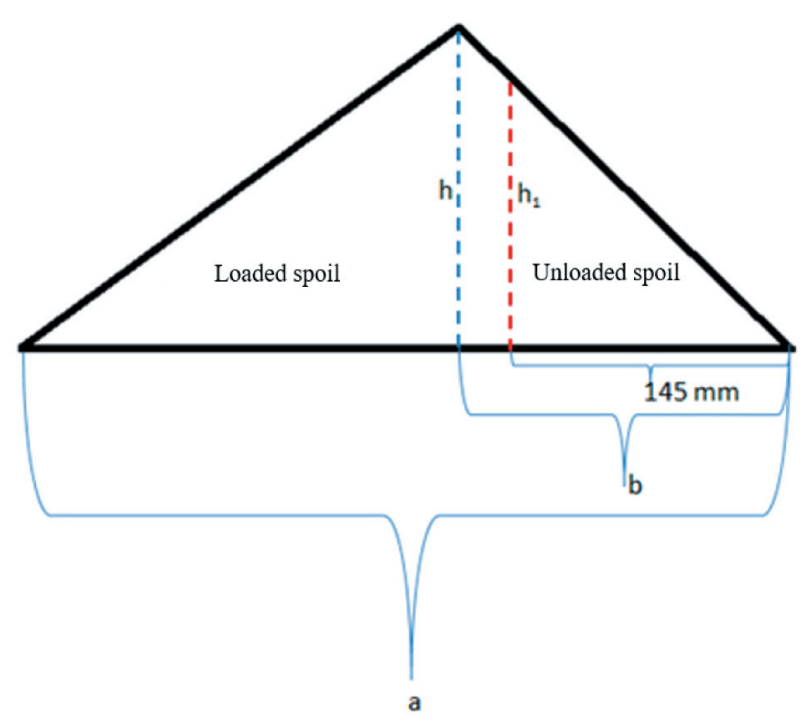

Fig. 7. Diagram of cross-section of spoil heap 
The tests were carried out in accordance with the following plan:

- a spot located within the sliding frame of the station was filled with the spoil of a specified and known granulation corresponding to the $k_{r}$ coefficient;

- the appropriate angle of the longitudinal inclination of the longwall working was set by using connectors of the appropriate length (Fig. 5);

- the feed drive and rotor of the drum were started in accordance with Table 1;

- the frame was stopped after having moved $1200 \mathrm{~mm}$, and the quantity of the spoil loaded was measured in accordance with Figure 7 (measurement of the geometry of the heap).

After performing the above-mentioned activities, the test procedure was repeated twice for all of the parameter values specified in Table 1.

\section{TEST RESULTS STUDY AND ANALYSIS}

In accordance with the test procedure described above, the drum without a shield loader was tested first, and the test station was set horizontally $\left(0^{\circ}\right.$ angle of the excavation slope). Then, the tests were carried out for three settings simulating the inclination of the longwall working for angles of $3^{\circ}, 6^{\circ}$, and $9^{\circ}$. The loading process was carried out along the strike for each of the inclination angles. The test results obtained after testing for the horizontal working served as a reference for the remaining slope settings.

After conducting a whole series of tests for each of the kinematic parameters (feed speed, rotational speed of the drum) and each setting of the angle of inclination of the working, all of the results were com- piled in a graphical and tabular manner. This allowed for an easier comparison and determination of the dependencies between them and an evaluation of the loading efficiency for the individual inclination angles.

Presented below are selected combinations of the test results. Figure 8 and Table 2 summarize the test results for the horizontal position and the drum without a loader. Figure 8 shows loading efficiency $\eta_{t}$ as a function of the fill factor of the drum for different feed speeds $v_{p}$. As can be seen in the chart below, the highest loading efficiency was obtained at the lowest feed speed and at the lowest filling of the drum. In addition, at a feed speed of $v_{p}=2 \mathrm{~m} / \mathrm{min}$, loading efficiency is the highest. However, for a feed speed of $v_{p}=6 \mathrm{~m} / \mathrm{min}$, the efficiency decreases with increases in the fill factor of the drum. In connection with the above, it can be assumed that, as the filling of the drum increases, the loading resistances increase accordingly and, thus, the loading efficiency decreases.

Comparing the results summarized in Table 2, we can conclude that the highest loading efficiency was obtained for a feed speed of $v_{p}=2 \mathrm{~m} / \mathrm{min}$ and the lowest fill factor of the drum $k_{w}$. However, the lowest loading efficiency was recorded for the highest $k_{w}$ coefficient and the highest feed speed $\left(v_{p}=6 \mathrm{~m} / \mathrm{min}\right)$.

The next stage of the research was to conduct tests for various longwall slopes. Presented below is an example graph of the loading efficiency (Fig. 9) as a function of the drum's fill factor and feed speed. The graph presented in Figure 9 clearly shows that, with increases in the feed speed $v_{p}$, as the drum becomes increasingly filled, there is a significant reduction in the loading efficiency. Similar dependencies were observed for the remaining inclination angles of the station (wall), an example of which is shown in Figure 10.

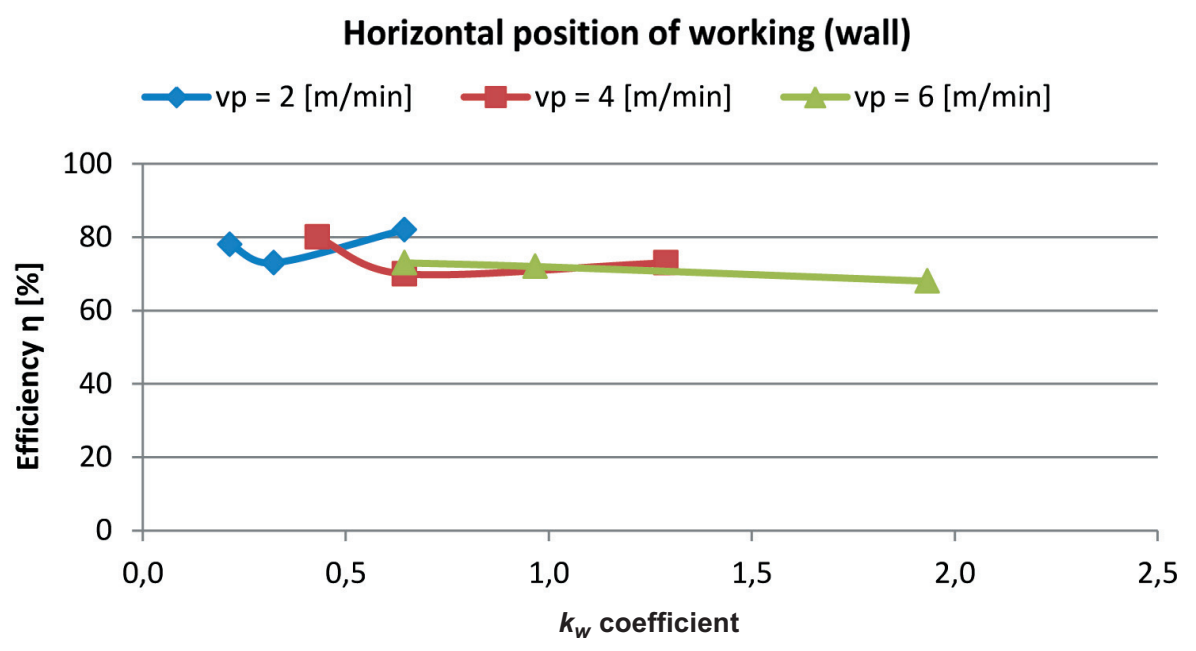

Fig. 8. Efficiency of loading $\eta$ in function of drum fill factor $k_{w}$ for different feed speeds $v_{p}$ for horizontal longwall 
Table 2

Test results for various kinematic parameters set during tests

\begin{tabular}{|c|c|c|c|c|c|c|c|c|c|c|}
\hline No. & $\begin{array}{c}\boldsymbol{v}_{\boldsymbol{p}} \\
{[\mathbf{m} / \mathbf{m i n}]}\end{array}$ & $\begin{array}{c}\boldsymbol{n} \\
{[\mathbf{r p m}]}\end{array}$ & $\boldsymbol{k}_{\boldsymbol{w}}$ & $\begin{array}{c}\boldsymbol{a} \\
{[\mathbf{m m}]}\end{array}$ & $\begin{array}{c}\boldsymbol{b} \\
{[\mathbf{m m}]}\end{array}$ & $\begin{array}{c}\boldsymbol{h} \\
{[\mathbf{m m}]}\end{array}$ & $\begin{array}{c}\boldsymbol{h}_{\mathbf{1}} \\
{[\mathbf{m m}]}\end{array}$ & $\begin{array}{c}\boldsymbol{P}_{\boldsymbol{c}} \\
{\left[\mathbf{c m}^{2}\right]}\end{array}$ & $\begin{array}{c}\boldsymbol{P}_{z} \\
{\left[\mathbf{c m}^{2}\right]}\end{array}$ & $\begin{array}{c}\boldsymbol{\eta} \\
{[\mathbf{\%}]}\end{array}$ \\
\hline 1 & 2 & 40 & 0.644 & 48 & 24.2 & 15 & 9 & 357 & 292 & 82 \\
\hline 2 & 2 & 80 & 0.322 & 42.3 & 18.6 & 19 & 15 & 396 & 290 & 73 \\
\hline 3 & 2 & 120 & 0.215 & 45.8 & 21.1 & 18 & 12 & 407 & 319 & 78 \\
\hline 4 & 4 & 40 & 1.288 & 42.2 & 18.5 & 14 & 11 & 306 & 223 & 73 \\
\hline 5 & 4 & 80 & 0.644 & 41.1 & 17.1 & 14 & 12 & 294 & 206 & 70 \\
\hline 6 & 4 & 120 & 0.429 & 46.5 & 22.2 & 11 & 8 & 267 & 213 & 80 \\
\hline 7 & 6 & 40 & 1.933 & 39.2 & 17 & 15 & 13 & 301 & 206 & 68 \\
\hline 8 & 6 & 80 & 0.966 & 41.7 & 18.2 & 14 & 11 & 290 & 210 & 72 \\
\hline 9 & 6 & 120 & 0.644 & 43 & 17.9 & 14 & 12 & 307 & 223 & 73 \\
\hline
\end{tabular}

Wall inclination $3^{\circ}$

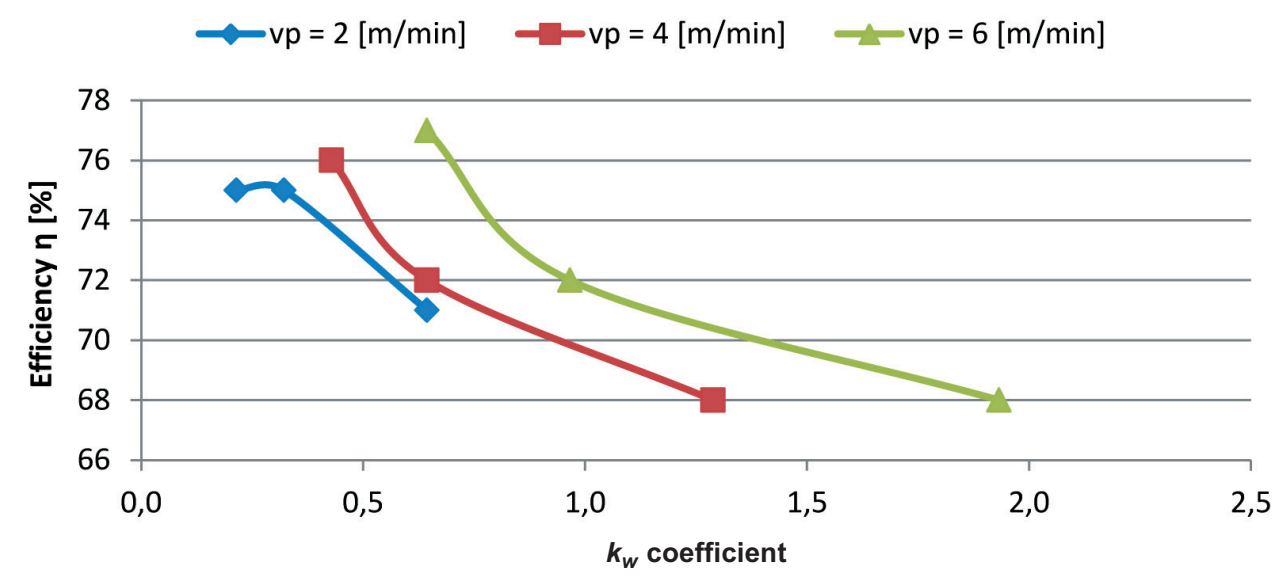

Fig. 9. Loading efficiency $\eta_{t}$ as a function of the drum fill factor $k_{w}$ for different feed speeds $v_{p}$ for a $3^{\circ}$ wall inclination

\section{Wall inclination $9^{\circ}$}

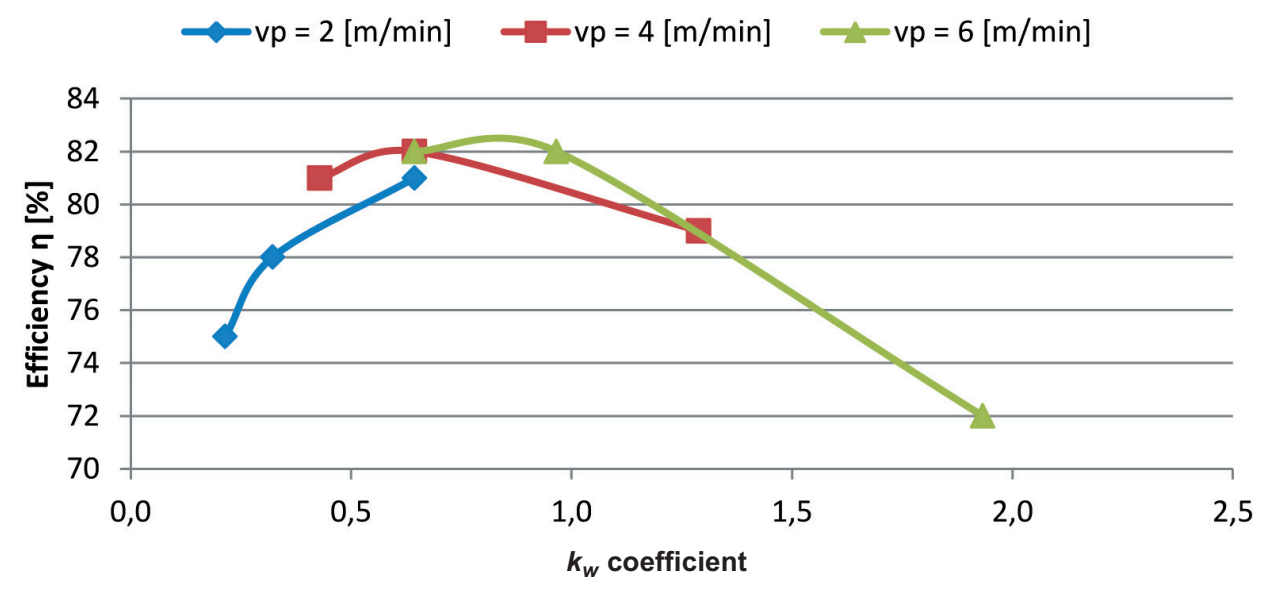

Fig. 10. Loading efficiency $\eta_{t}$ as function of drum fill factor $k_{w}$ for different feed speeds $v_{p}$ for $9^{\circ}$ wall inclination 
The graph shown in Figure 10 also shows that, at a $9^{\circ}$ wall inclination and for higher feed speeds, the drum's fill factor increases and, thus, the loading efficiency is significantly reduced.

\section{CONCLUSIONS}

As mentioned earlier, the conducted research should be considered as a pilot study on the subject of the loading of spoil with worm-type cutting drums for inclined workings. The laboratory tests carried out and the subsequent analysis of the test results allowed us to draw conclusions and indications for further research (tests) on this topic. The main conclusion from the research is that the inclination of the working impacts the loading process because, with increases in the inclination angle, the efficiency of the loading with a drum without a loader decreases slightly. All of the experiments were carried out to simulate a shearer moving along the spike. The tests also indicate that, with increases in the feed speed and angle of inclination of the wall, the filling of the drum increases, thus affecting the efficiency of the loading.

These tests were the first tests of the loading process with a longitudinal inclination of a wall conducted at the Department of Mining, Dressing and Transport Machines of AGH. Previously, only tests for horizontal walls had been carried out. In connection with the above, tests should be continued for the longitudinal inclination of a station for greater angles and for drums with shield loaders. Perhaps for larger wall inclinations and with the use of a shield loader, an increase in power of the drum's rotor and feed motor will be visible during the tests. It is also suggested to introduce a system for collecting the spoil at the station, which could better illustrate the loading process.

\section{References}

[1] Szlązak N., Szlązak J.: Wentylacja wyrobisk ścianowych w kopalniach wegla kamiennego, $w$ warunkach zagrożeń metanowego i pożarowego, "Górnictwo i Geologia" 2013, 8, 2: $115-131$
[2] Borówka B.: Próba oceny technicznych możliwości eksploatacji zasobów pozabilansowych $w$ kopalni węgla kamiennego, "Górnictwo i Geoinżynieria" 2010, 34, 3: 169-185.

[3] Jaszczuk M.: Ścianowe systemy mechanizacyjne, Wydawnictwo Naukowe "Śląsk", Katowice 2007.

[4] Krauze K.: Urabianie skat kombajnami ścianowymi, Wydawnictwo Naukowe "Śląsk", Katowice 2000.

[5] Bołoz Ł.: Maszyny urabiające w ścianowych systemach eksploatacji cienkich pokładów węgla kamiennego, "Systemy Wspomagania w Inżynierii Produkcji. Górnictwo - Perspektywy i Zagrożenia: Węgiel, Tania Czysta Energia i Miejsca Pracy" 2018, 7, 1: 143-154.

[6] Bołoz Ł.: Longwall shearers for exploiting thin coal seams as well as thin and highly inclined coal seams, "Mining - Informatics, Automation and Electrical Engineering" 2018, 2: $59-72$.

[7] Korski J., Bednarz R.: Kombajnowy system ścianowy jako efektywna alternatywa dla strugów węglowych, "Mechanizacja i Automatyzacja Górnictwa" 2012, 50, 9: 31-38.

[8] Krauze K., Wydro T., Bołoz Ł.: Problemy zwiazane z procesem tadowania frezującymi organami ślimakowymi, in: Problemy bezpieczeństwa $w$ budowie i eksploatacji maszyn $i$ urzadzeń górnictwa podziemnego. Monografia, red. K. Krauze, Lędziny 2010: 124-133.

[9] Krauze K., Wydro T.: Badania laboratoryjne procesu tadowania frezującymi organami ślimakowymi, in: Innowacyjne techniki i technologie dla górnictwa. Monografia, red. nauk. A. Klich, A. Kozieł, Instytut Techniki Górniczej KOMAG, Gliwice 2010: 387-404.

[10] Hamala K., Wydro T.: Stanowisko do badań procesu tadowania frezującym organem ślimakowym, "Maszyny Górnicze" 2005, 1: 17-21.

[11] Wydro T.: Badania laboratoryjne procesu tadowania frezującymi organami ślimakowymi przy różnym stopniu ich wypetnienia $i$ granulacji urobku, AGH Akademia Górniczo-Hutnicza im. Stanisława Staszica w Krakowie, Kraków 2011 [Ph.D. thesis].

[12] Jaszczuk M.: Kombajnowe systemy mechanizacyjne, "Skrypty Uczelniane" nr 1224, Gliwice 1986.

[13] Krauze K., Wydro T.: Analiza wyników badań procesu ładowania frezującymi organami ślimakowymi, in: Zagadnienia mechaniki pękania i skrawania materiałów. Monografia, red. J. Jonak, Lubelskie Towarzystwo Naukowe, Lublin 2010: $140-156$.

[14] Krysicki W. et al.: Rachunek prawdopodobieństwa i statystyka matematyczna $w$ zadaniach, część 2, Wydawnictwo Naukowe PWN, Warszawa 1999.

TOMASZ WYDRO, Ph.D., Eng. Department of Mining, Dressing and Transport Machines

Faculty of Mechanical Engineering and Robotics AGH University of Science and Technology al. Mickiewicza 30, 30-059 Krakow, Poland wydro@agh.edu.pl 


\title{
Badania sprawności ładowania frezującym organem ślimakowym przy nachyleniu podłużnym wyrobiska ścianowego
}

\begin{abstract}
W artykule przedstawiono realizacje oraz wyniki badań sprawności ładowania frezujacymi organami ślimakowymi w funkcji nachylenia wyrobiska ścianowego. Badania zostały przeprowadzone przy różnych kątach nachylenia podtużnego wyrobiska ścianowego $w$ zakresie od $0^{\circ}$ do $9^{\circ}$ po wzniosie. W warunkach rzeczywistych rozdzielenie dwóch podstawowych procesów, jakie zachodza podczas pracy kombajnu ścianowego, czyli frezowania i ładowania nie jest możliwe, w zwiazku z tym badania zostaty przeprowadzone w warunkach laboratoryjnych w Katedrze Maszyn Górniczych, Przeróbczych $i$ Transportowych Akademii Górniczo-Hutniczej w Krakowie. Badania wykonano na specjalnym stanowisku pozwalajacym na skokowa zmianę nachylenia podtużnego i poprzecznego wyrobiska ścianowego. Na podstawie ich wyników stwierdzono, że nachylenie wyrobiska ścianowego wpływa na sprawność ładowania, co oznacza, że wraz ze wzrostem kata nachylenia podtużnego opory tadowania rosna, a sprawność ładowania maleje.
\end{abstract}

Słowa kluczowe: badania laboratoryjne, tadowanie urobku, organy ślimakowe

\section{WSTĘP}

Wydobycie węgla kamiennego w większości krajów europejskich, w tym także w Polsce, generalnie odbywa się metodami ścianowymi, a w szczególności kombajnowymi kompleksami ścianowymi. System ścianowy posiada wiele zalet, do których można zaliczyć: niewielkie straty eksploatacyjne, małą liczbę robót przygotowawczych, zmniejszenie niebezpieczeństwa wystąpienia tąpań (dzięki dogodnemu rozkładowi naprężeń w górotworze), zmniejszenie niebezpieczeństwa powstawania pożarów za sprawą czystego wybierania złoża oraz możliwość przewietrzania obiegowym prądem powietrza [1]. Jednak każde wyrobisko ścianowe charakteryzuje się indywidualnymi zagrożeniami i utrudnieniami w eksploatacji węgla. Do takich zagrożeń należą tak zwane zagrożenia skojarzone: pożarowe, tąpaniami, temperaturowe i metanowe [1]. Natomiast do utrudnień z technicznego punktu widzenia należą niewątpliwie ściany o wysokości poniżej 1,5 m oraz nachylenie wyrobiska (kąt upadu po- kładu). Tak jak w przypadku określenia zakresów wysokości ścian w poszczególnych kategoriach, nachylenie pokładu też jest kwestią umowną i do najczęściej spotykanych podziałów należy $[2,3]$ :

- ułożone poziomo $<5^{\circ}$,

- ułożone prawie poziomo $5-15^{\circ}$,

- słabo nachylone $15-30^{\circ}$,

- silnie nachylone $30-45^{\circ}$,

- strome $>45^{\circ}$.

Mając na uwadze sposób prowadzenia wyrobisk ścianowych, ich odniesienie do nachylenia pokładu i kierunku eksploatacji, możemy wyróżnić nachylenie ścian podłużne i poprzeczne. Jeżeli czoło ściany przemieszcza się prostopadle do nachylenia pokładu (rys. 1), ścianę taką nazywamy ścianą podłużną. Natomiast gdy czoło ściany przemieszcza się równolegle po wzniosie lub upadzie do nachylenia pokładu, ścianę określa się jako ścianę poprzeczną (rys. 2) [4].

W praktyce górniczej w przypadku pokładów nachylonych dąży się do takiej orientacji wyrobiska, by 
kąt nachylenia poprzecznego ściany był jak najmniejszy, dopuszczając większe wartości kąta nachylenia podłużnego - nawet $45^{\circ}$. Wynika to głównie z możliwości eksploatacyjnych maszyn i urządzeń pracujących w ścianie [4]. Przykładem kombajnów ścianowych pracujących przy dużym nachyleniu podłużnym są kombajny firmy Beijing HOT Mining Tech (rys. 3) [5, 6].

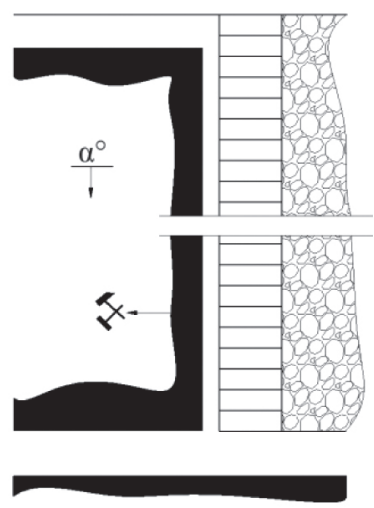

Rys. 1. Ściana nachylona podtużnie
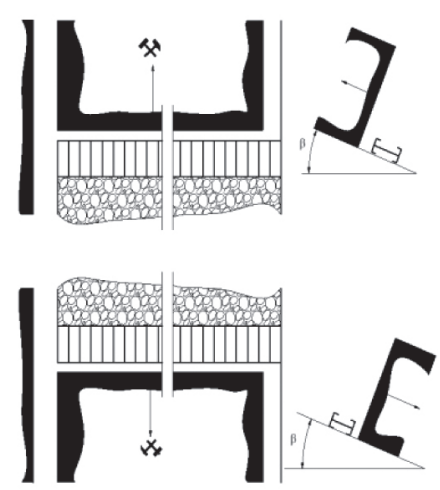

Rys. 2. Ściana nachylona poprzecznie

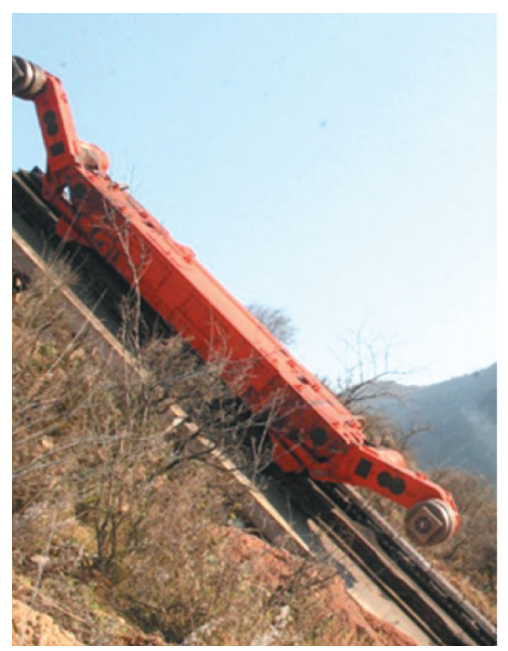

Rys. 3. Klasyczny kombajn ścianowy do stromych pokładów na poligonie firmy Beijing HOT Mining Tech [5]
Jak wynika z literatury zakres dopuszczalnych nachyleń dla zmechanizowanych kompleksów ścianowych to: podłużnie do $45^{\circ}$, a poprzecznie do $\pm 20^{\circ}$. Należy zauważyć, że najlepsze wyniki uzyskują ściany zmechanizowane w poziomych lub słabo nachylonych pokładach, a wraz ze wzrostem nachylenia wydajność ścian znacząco spada [6].

Stąd mając na uwadze powyższe dane literaturowe, sprawdzono, w jakim stopniu kąt nachylenia podłużnego wyrobiska ścianowego ma wpływ na proces ładowania frezującymi organami ślimakowymi, a tym samym na uzyskanie wydajności tego procesu.

Proces ładowania jest kluczowy, ponieważ występuje konieczność ciągłego odprowadzania urobku powstającego w procesie urabiania na przenośnik ścianowy. Czyszczenie ścieżki kombajnowej umożliwia przestawienie kompleksu w nowe pole o pełny zabiór. Pozostawienie urobku na ścieżce kombajnowej może prowadzić do tak zwanego gubienia zabioru, czyli przesunięcia przenośnika o zabiór mniejszy od zakładanego (wymaganego). Taka sytuacja wpływa na to, że organy nie mogą pracować na całej szerokości, czego skutkiem jest nieosiąganie założonego wydobycia dobowego. Drugim niekorzystnym efektem jest tak zwane podbijanie przenośnika, polegające na jego podnoszeniu na pozostawionym urobku. To może powodować trudności w utrzymaniu pracy kombajnu na wysokości założonej dla danej ściany. Ponadto może prowadzić do zmniejszenia trwałości noży kombajnowych przez to, że organy urabiające wcinają się w skały stropowe [7].

\section{CEL I ZAŁOŻENIA BADAŃ}

Celem przedmiotowych badań było określenie wpływu kąta podłużnego wyrobiska ścianowego na sprawność ładowania. Jak znajdujemy w literaturze [3], maksymalne nachylenie podłużne ścian średnich może wynosić $-35^{\circ}$, natomiast poprzeczne przy prowadzeniu ściany po wzniosie $20^{\circ}$, a po upadzie $15^{\circ}$. W związku z powyższym wartości kątów wybrane do badań będą reprezentatywne dla ścian prawie poziomych. Badania przeprowadzono dla czterech kątów nachylenia wyrobiska, jako że są to badania pilotażowe w temacie rozpoczęto od najniższych wartości kątów nachylenia. Dla wyrobiska poziomego o kącie $0^{\circ}$ oraz trzech kątów nachylenia podłużnego: $3^{\circ}, 6^{\circ}, 9^{\circ}$. Również stanowisko, na którym zrealizowano pomiary sprawności ładowania, ma możliwości zastosowania tych kątów podczas badań. 
Podczas badań uwzględniono wartości współczynników wypełnienia organu $k_{w}$ i współczynnik rozluzowania $k_{r}$ urobku, które mają wpływ na sprawność ładowania. Zakres i wartość tych współczynników zostały określone na podstawie badań empirycznych i przyjmowane są $\mathrm{w}$ granicach $k_{w}=0-1, k_{r}>1$ [8]. Do interpretacji wyników badań został przyjęty model analityczny procesu ładowania frezującymi organami ślimakowymi [4, 9]. Zgodnie z przyjętym celem pracy założono, że proces ładowania zostanie rozdzielony od procesu frezowania, aby można było skupić się tylko na ładowaniu. To założenie możliwe było do zrealizowania tylko w warunkach badań laboratoryjnych.

W związku z powyższym badania procesu ładowania miały charakter laboratoryjny i zostały przeprowadzone na specjalnie do tego celu przygotowanym stanowisku badawczym. Stanowisko to umożliwia realizację procesu ładowania, a także zastosowanie różnych kątów nachylenia podłużnego i poprzecznego wyrobiska ścianowego. Do badań został wykorzystany specjalnie zaprojektowany frezujący organ ślimakowy o określonym kącie nawinięcia płatów ślimaka.

\section{PLAN I METODYKA BADAŃ}

Głównym założeniem badania sprawności ładowania ślimakowymi organami urabiającymi było sprawdzenie, w jakim stopniu nachylenie podłużne wyrobiska ścianowego ma wpływ na jakość (sprawność) procesu ładowania. Badania należało wykonać zgodnie z zależnościami określającymi prawidłowy przebieg procesu ładowania, czyli tak, by objętość wewnętrzna organu $V_{o}$, była większa od ilości urobku powstającego podczas urabiania $V_{u}$ dla jednego lub dwóch organów. Zależności te zostały opisane w literaturze [4] dla pracy organów z ładowarkami i bez ładowarek. W równaniach (opisanych w literaturze w [4]) występują takie parametry, jak objętości organu przedniego i tylnego, które można opisać za pomocą zależności:

- objętość urobku dla organu przedniego:

$$
V_{u p}=V_{u} \frac{D_{s} z v_{p} k_{r} k_{L}}{n}
$$

- objętość urobku dla organu tylnego:

$$
V_{u t}=\frac{\left(H-D_{s}\right) z v_{p} k_{r} k_{L}}{n}
$$

gdzie:

$V_{u}$ - wydajność urabiania organu $[\mathrm{Mg} / \mathrm{h}]$,

$D_{s}$ - średnica organu $[\mathrm{m}]$,

$H$ - wysokość urabianej ściany [m],

$Z$ - zabiór [m],

$k_{r}$ - współczynnik rozluzowania urobku [-],

$k_{L}$ - współczynnik określający ilość załadowanego urobku bez udziału organu [-],

$k_{w}$ - współczynnik wypełnienia organu [-].

W związku z powyższym do badań przeznaczono tylko jeden organ, przedni, gdyż on zawsze urabia caliznę całą średnicą. Współczynnik $k_{L}$ został przyjęty równy 1 . Oznacza to, że cały urobek zostanie załadowany za pomocą frezującego organu ślimakowego. Z zależności (1) wynika, że:

$$
k_{w} \geq \frac{D_{s} \cdot z}{v_{o}} \cdot \frac{v_{p}}{n} \cdot k_{r}
$$

gdzie:

$$
\begin{aligned}
& \frac{D_{s} \cdot z}{v_{o}}-\text { parametry konstrukcyjne organu, } \\
& \frac{v_{p}}{n}-\text { parametry kinematyczne. }
\end{aligned}
$$

Ze wzoru (3) ustalono wymagane dla danych warunków parametry konstrukcyjne organu, lecz bez układu nożowego.

Na potrzeby badań laboratoryjnych konieczne było utworzenie urobku o założonym wcześniej składzie ziarnowym. Zastosowanie urobku o określonym składzie ziarnowym pozwoliło na uzyskanie różnych wartości współczynnika rozluzowania urobku $k_{r}$. Dla określonego urobku oraz danego organu ślimakowego, zmiana prędkości posuwu i prędkości obrotowej organu determinuje wartość współczynnika wypełnienia organu $k_{w}$.

Parametrami mierzonymi podczas badań będą:

- pobór mocy oporów ładowania $N_{p}$ mierzony na silniku posuwu w funkcji sprawność ładowania organem $\eta_{t}$,

- pobór mocy oporów ładowania $N_{o}$ mierzony na silniku organu w funkcji sprawność ładowania organem $\eta_{t}$,

- sprawność ładowania organem $\eta_{t}$, mierzona jako przekrój poprzeczny pryzmy urobku $[9,11]$. 
Tabela 1

Wartości współczynnika wypełnienia organu $k_{w}$ i współczynnika rozluzowania $k_{r}$

\begin{tabular}{|c|c|c|c|c|c|c|c|c|c|c|}
\hline \multirow[t]{2}{*}{ Lp. } & \multirow{2}{*}{$\begin{array}{c}\text { Współczynnik } \\
\text { rozluzowania } \\
k_{r} \\
\text { (granulacja) }\end{array}$} & \multirow{2}{*}{$\begin{array}{c}\text { Prędkość } \\
\text { obrotowa } \\
\text { organu } \\
n \text { [obr } / \mathbf{m i n}]\end{array}$} & \multicolumn{8}{|c|}{$\begin{array}{c}\text { Prędkość posuwu } \\
\qquad v_{p}[\mathrm{~m} / \mathrm{min}]\end{array}$} \\
\hline & & & 1 & 2 & 3 & 4 & 5 & 6 & 7 & 8 \\
\hline 1 & \multirow{3}{*}{$\begin{array}{c}1,69 \\
(0-45 \mathrm{~mm})\end{array}$} & 40 & 0,322 & 0,644 & 0,967 & 1,289 & 1,611 & 1,933 & 2,256 & 2,578 \\
\hline 2 & & 80 & 0,161 & 0,322 & 0,483 & 0,644 & 0,806 & 0,967 & 1,128 & 1,289 \\
\hline 3 & & 120 & 0,107 & 0,215 & 0,322 & 0,430 & 0,537 & 0,644 & 0,752 & 0,859 \\
\hline
\end{tabular}

Zakres wartości prędkości obrotowej $n$ oraz prędkości posuwu $v_{p}$ został ustalony na podstawie rzeczywistych parametrów konstrukcyjnych i kinematycznych organu ślimakowego użytego do badań.

Wartości tych parametrów (tab. 1) są odzwierciedleniem wartości parametrów stosowanych w warunkach rzeczywistych (prędkość obrotowa organu, prędkość posuwu). Do sporządzenia tej tabeli posłużyła zależność (3). Tabela ilustruje teoretyczne wartości współczynnika wypełnienia organu $k_{w}$ w zależności od prędkości posuwu $v_{p}$ i prędkości obrotowej organu $n$ dla różnych współczynników rozluzowania urobku $k_{r}$. Umożliwia ona łatwy i szybki dobór prędkości posuwu i prędkości obrotowej organu w celu otrzymania wymaganego w danym badaniu współczynnika wypełnienia organu.

Przedstawione w tabeli 1 wartości umożliwiają realizację badań dla trzech kątów nachylenia podłużnego wyrobiska ścianowego, a mianowicie dla $3^{\circ}, 6^{\circ}$ i $9^{\circ}$. Na podstawie przeprowadzonych badań i uzyskanych wyników możliwe będzie dokonanie analizy i oceny wpływu kąta nachylenia wyrobiska na sprawność łado-

a)

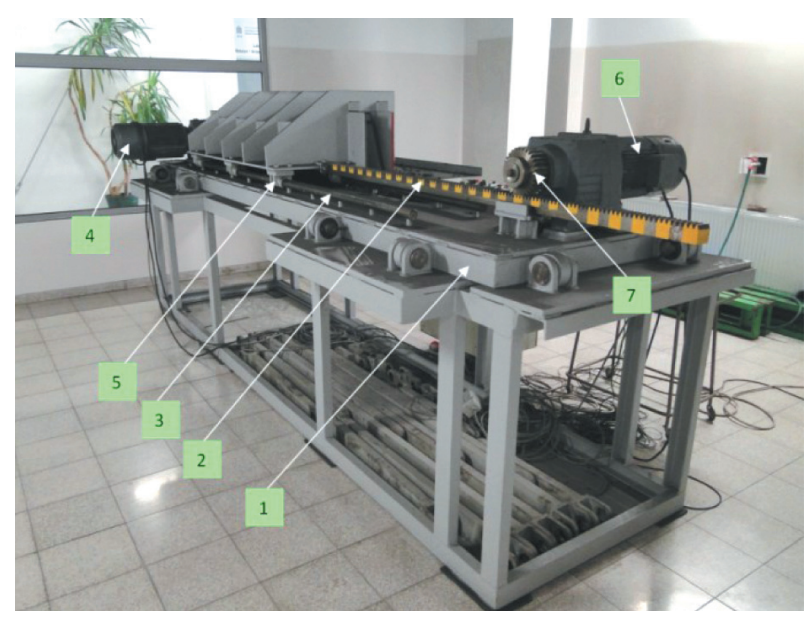

wania w funkcji prędkości obrotowej organu i prędkości posuwu przy uwzględnieniu współczynnika wypełnienia organu $k_{w}$ i współczynnika rozluzowania $k_{r}$.

\section{STANOWISKO LABORATORYJNE DO BADANIA PROCESU ŁADOWANIA FREZUJĄCYMI ORGANAMI ŚLIMAKOWYMI}

Stanowisko laboratoryjne (rys. 4a) przeznaczone do badania procesu ładowania składa się części konstrukcyjnej oraz układu pomiarowego. Część konstrukcyjną stanowiska stanowi rama przesuwna, z zabudowanymi na niej kadłubem organu urabiającego (rys. 4b). Napęd posuwu (koło zębate i listwa zębata) umożliwia ruch ramy po prowadnicach, realizując w ten sposób przemieszczanie się organu podczas pracy.

Silnik napędu posuwu pozwala na regulację prędkości liniowej ramy. Dwie prowadnice umożliwiają przesuw ramy na dystansie $1200 \mathrm{~mm}$. Układ zasilania silnika napędu obrotów organu umożliwia zmianę kierunków oraz regulację prędkości obrotowej organu.

b)

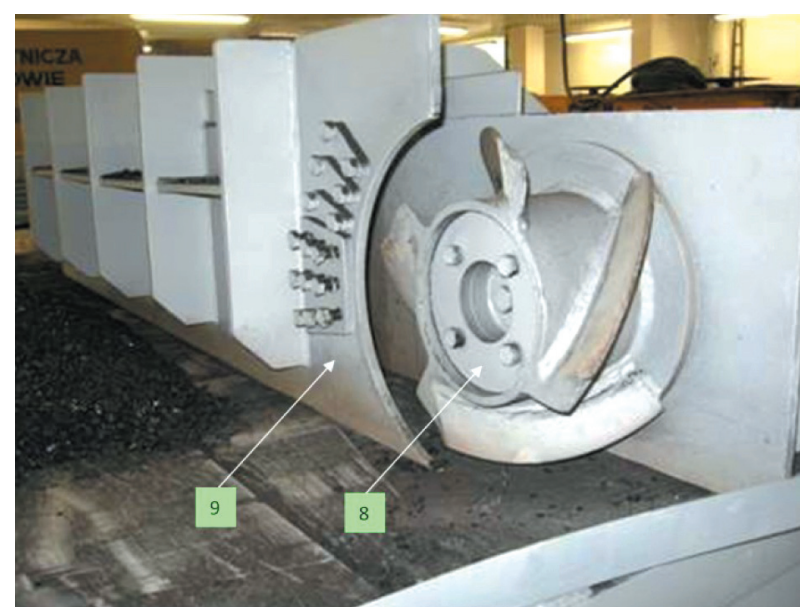

Rys. 4. Stanowisko do badań procesu ładowania: a) widok stanowiska badawczego od strony silnika posuwu i listwy;

b) widok od strony organu: 1 - podstawa stanowiska, 2 - listwa zębata, 3 - prowadnice, 4 - silnik napędu organu, 5 - ślizgi, 6 - silnik napędu posuwu, 7 - koło zębate, 8 - organ urabiający, 9 - rama przesuwna 

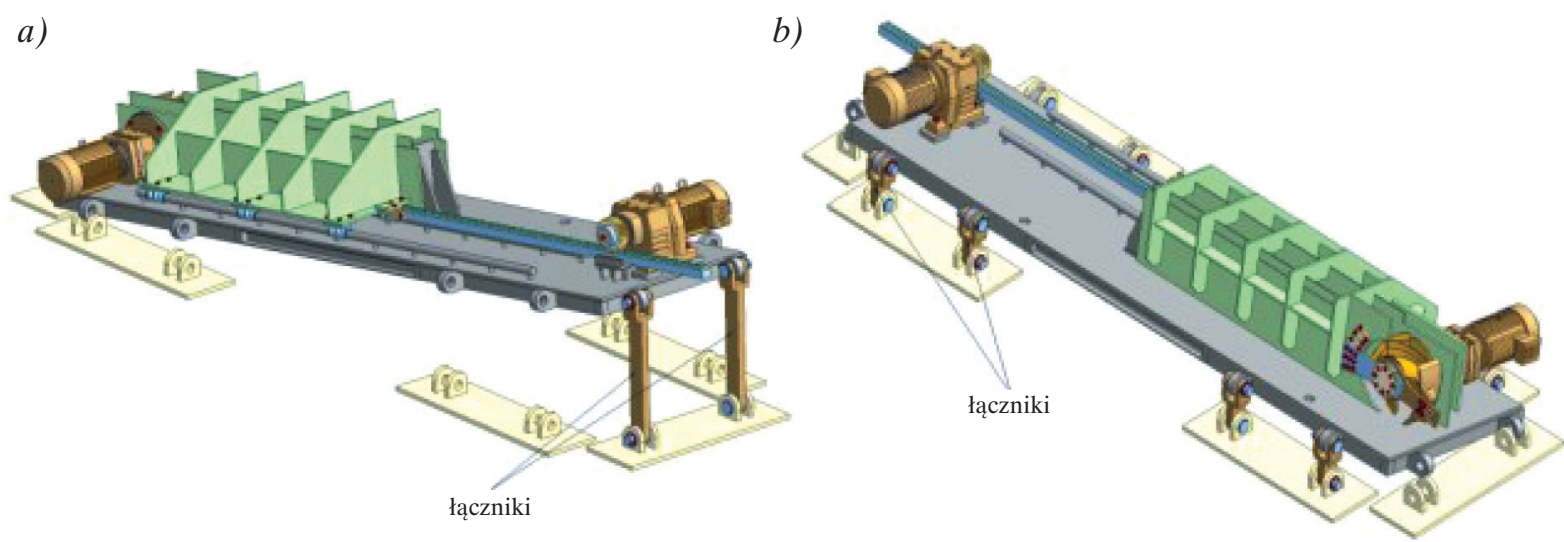

Rys. 5. Stanowisko do badania procesu tadowania: a) nachylenie podtużne;

b) nachylenie poprzeczne

Konstrukcja ramy przesuwnej umożliwia usypanie pomiędzy jej blachami pryzmy ładowanego urobku [3]. Stanowisko umożliwia regulacje podstawowych parametrów kinematycznych elementów stanowiska, takich jak:

- prędkości liniowej ramy nośnej (prędkość posuwu),

- prędkości obrotowej organu,

- kierunków obrotu organu,

- kierunku posuwu (ruch ramy).

Stanowisko umożliwia ustawienie kąta nachylenia podłużnego i porzecznego, tak jak to przedstawiono na rysunku 5. Nachylenie stanowiska można uzyskiwać dzięki łącznikom, które mają różną długość i odpowiadają odpowiednim kątom.

Do badań został przeznaczony organ ślimakowy czterowchodowy o płatach normalnych bez ładowarki osłonowej. Dobór organu do badań został oparty o literaturę fachową oraz wcześniejsze badania, które zostały opisane w pozycji [10]. Przedmiotowy organ charakteryzuje się następującymi parametrami:

- $Z_{U}=0,133 \mathrm{~m}$,

- $D=0,334 \mathrm{~m}$,

$-d=0,2 \mathrm{~m}$,

- $b=0,012 \mathrm{~m}$,

$-i=4$,

$-\alpha_{2}=28,33^{\circ}$,

$-k_{k p}=1$, gdzie:

$Z_{U}$ - zabiór organu bez tarczy odcinającej (część urabiająco-ładująca) [m],

$D$ - średnica bębna organu $\mathrm{z}$ uwzględnieniem nakładek ładujących [m],

$d$ - średnica piasty organu $[\mathrm{m}]$,

$b$ - grubość płata [m],

$i$ - liczba płatów [-],

$\alpha_{2}$ - kąt nawinięcia płata $\left[^{\circ}\right]$,

$k_{k p}$ - współczynnik uwzględniający kształt piasty organu zdefiniowany jako stosunek objętości innej niż walcowa do objętości walca piasty $d[-]$.

Część pomiarową stanowiska stanowił specjalnie zaprojektowany układ pomiarowy, który pozwala zmierzyć i zarejestrować pobór mocy na obu silnikach.

Zastosowany układ pomiarowy na stanowisku badawczym został wyposażony w przekładniki prądowe, przetworniki mocy czynnej, moduł pomiarowy i komputer pomiarowy (rys. 6).

Pomiar prędkości obrotowej na silnikach S, realizowany był przez enkodery E, z których sygnały przekazywane były do skrzyni zasilającej. W skrzyni zasilającej sygnał przekazywany jest do falownika $\mathrm{F}$ oraz przez przekładniki prądowe PP, przetworniki mocy czynnej PMC i kartę pomiarową KP (stacje dokująca) do komputera $\mathrm{K}$, w którym następuje zapis danych.

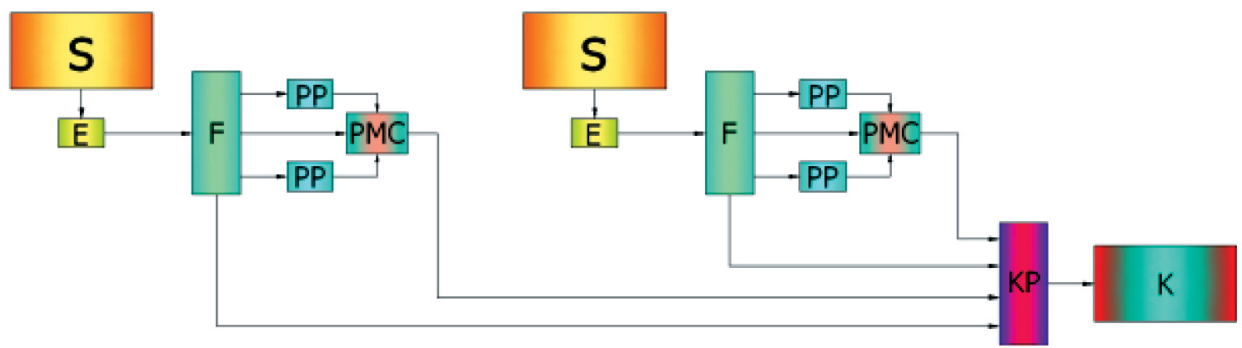

Rys. 6. Schemat uktadu pomiarowego stanowiska badawczego [10] 


\section{PRZEPROWADZENIE BADAŃ WSTEPNYCH}

Założono również, że badania będą miały charakter dwuetapowy, a mianowicie badania wstępne i zasadnicze. Badania wstępne miały na celu stwierdzenie, czy układ pomiarowy działa w sposób prawidłowy, czy przyjęte założenia do badań są słuszne oraz określenie niezbędnej liczby powtórzeń pomiarów podczas badań zasadniczych. W związku z powyższym dla stałych obrotów organu i prędkości posuwu wykonano trzy pomiary. Wyniki opracowano statystycznie według metody Steina [14]. Następnie z rozkładu $t$-Studenta przyjęto, że wystarczające jest wykonanie dwóch prób dla każdego zestawienia parametrów.

Na podstawie badań wstępnych sformułowano szereg wniosków. Podczas pracy organu bez ładowarki nie stwierdzono wzrostu poboru mocy na żadnym z silników. Zaobserwowano natomiast, że w miarę wzrostu wartości współczynnika wypełnienia $k_{w}$ zmienia się kształt i położenie pryzmy urobku.

W związku z powyższym przyjęto, że głównym kryterium oceny procesu ładowania dla organu bez ładowarki będzie tylko sprawność ładowania.

Za sprawność ładowania uznano stosunek pola przekroju pryzmy urobku załadowanego do pola przekroju całkowitego pryzmy urobku przemieszczonego [8]. Przyjęto więc, że przekrój pryzmy będzie ilustrował trójkąt (rys. 7), którego wielkości $a, b, h$ zostaną zmierzone, dzięki czemu można będzie wyznaczyć sprawność ładowania dla danego pomiaru. Widoczny na rysunku 7 wymiar $145 \mathrm{~mm}$ wynika $\mathrm{z}$ zabioru organu urabiającego i jest on rozgraniczeniem pomiędzy urobkiem załadowanym i niezaładowanym. Sprawność ładowania $\eta_{t}$ dla wszystkich prób obliczono w ten sam sposób. Czyli jako iloraz pola przekroju urobku załado-

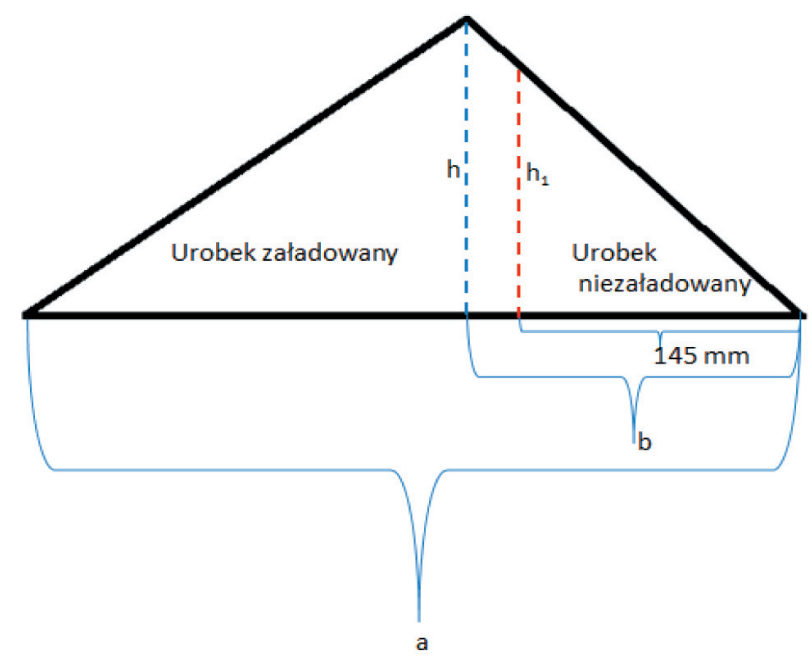

Rys. 7. Schemat przekroju pryzmy urobku wanego $P_{t \text { średnie }} \mathrm{i}$ średniego pola przekroju $P_{c \text { średnie }}$ całkowitego urobku pomnożone przez $100 \%$. Dla obliczenia sprawności ładowania wykorzystano zależność:

$$
\eta_{t}=\frac{P_{t \text { średnie }}}{P_{\text {ćśrednie }}} 100 \%
$$

\section{REALIZACJA BADAŃ ZASADNICZYCH}

Do badań wykorzystano węgiel z jednej z polskich kopalń. Węgiel przeznaczony do badań został dobrany pod względem własności i klasy ziarnistości do zaprojektowanego organu badawczego.

Przygotowanie urobku zostało przeprowadzone w Akredytowanym Laboratorium Badania i Własności Skał Wyrobów Kamieniarskich w Akademii Górniczo-Hutniczej. Celem przygotowania urobku było wyodrębnienie frakcji oraz określenie gęstości nasypowej w stanie luźnym. Na podstawie gęstości objętościowej ziaren węgla, czyli gęstości, jaką węgiel ma w caliźnie oraz gęstości nasypowej jego granulacji należało określić tzw. współczynnik rozluzowania urob$\mathrm{ku} k_{r}$. Gęstość objętościową określono zgodnie z normą PN-EN 1097-6, a gęstość nasypową zgodnie z wymogami normy PN-EN 1097-3:2000. Podczas określania współczynnika $k_{r}$ uwzględniono również parametry geometryczne organu użytego do badań [10]. Węgiel przeznaczony do badań miał granulację $0-45 \mathrm{~mm}$ oraz współczynnik rozluzowania urobku $k_{r}=1,69$. Współczynnik $k_{r}$ został przyjęty na podstawie badań eksperymentalnych i danych literaturowych [11-13]. Badania przeprowadzono zgodnie z następującym planem:

- miejsce, które znajduje się w ramie przesuwnej stanowiska, zostało zasypane urobkiem o określonej i znanej granulacji odpowiadającej współczynnikowi $k_{r}$;

- ustawiono odpowiedni kąt nachylenia podłużnego wyrobiska ścianowego dzięki zastosowaniu łączników odpowiedniej długości (rys. 5);

- uruchomiono napęd posuwu i obroty organu (tab. 1);

- ramę po przebyciu $1200 \mathrm{~mm}$ zatrzymano, a następnie dokonano pomiaru ilości urobku załadowanego zgodnie z rysunkiem 7 (pomiar geometrii pryzmy).

Po wykonaniu wyżej wymienionych czynności procedura badań była powtarzana kolejno dwukrotnie dla wszystkich wartości parametrów określonych w tabeli 1. 


\section{OPRACOWANIE I ANALIZA WYNIKÓW BADAŃ}

Zgodnie $\mathrm{z}$ opisaną procedurą badaniom jako pierwszy został poddany organ bez ładowarki osłonowej, a stanowisko badawcze ustawiono poziomo (kąt nachylenia wyrobiska $0^{\circ}$ ). Następnie badania przeprowadzono przy trzech ustawieniach symulujących nachylenie wyrobiska ścianowego, dla kątów: $3^{\circ}, 6^{\circ}$ i $9^{\circ}$. Realizacja procesu ładowania odbywała się po wzniosie dla każdego z ustawionych kątów nachylenia wyrobiska. Wyniki badań otrzymane po przeprowadzeniu prób dla poziomego wyrobiska były odniesieniem dla pozostałych ustawień nachylenia.

Po przeprowadzeniu całej serii badań dla każdego z parametrów kinematycznych (prędkość posuwu, prędkość obrotów organu) i każdego ustawienia kąta nachylenia wyrobiska wszystkie wyniki zestawiono w sposób graficzny i tabelaryczny. To pozwoliło na łatwiejsze porównanie i określenie zależności występujących pomiędzy nimi oraz oceny sprawności ładowania dla poszczególnych kątów nachylenia.

Poniżej przedstawiono wybrane zestawienia wyników badań. Na rysunku 8 i w tabeli 2 zestawiono wyniki badań dla stanowiska poziomego i organu bez ładowarki. Rysunek 8 przedstawia sprawność ładowania $\eta_{t}$ w funkcji współczynnika wypełnienia organu dla różnych prędkości posuwu $v_{p}$. Jak można zauważyć, na poniższym wykresie największą sprawność ładowania uzyskano przy najmniejszej prędkości posuwu i przy najniższym wypełnieniu organu. Ponadto przy prędkości posuwu $v_{p}=2 \mathrm{~m} / \mathrm{min}$ sprawność ładowania jest największa. Natomiast dla prędkości posuwu $v_{p}=6 \mathrm{~m} / \mathrm{min}$ sprawność maleje wraz ze wzrostem współczynnika wypełnienia organu. W związku z powyższym można przyjać, że wraz ze wzrostem wypełnienia organu wzrastają opory ładowania, a tym samym spada sprawność ładowania.

Porównując wyniki zestawione w tabeli 2, możemy stwierdzić, że najwyższe sprawności ładowania uzyskano dla prędkości posuwu $v_{p}=2 \mathrm{~m} / \mathrm{min}$ i najniższego współczynnika wypełnienia organu $k_{w}$. Natomiast najniższą sprawność ładowania odnotowano dla najwyższego współczynnika $k_{w}$ i najwyższej wartości prędkości posuwu $v_{p}=6 \mathrm{~m} / \mathrm{min}$.

Kolejnym etapem badań było przeprowadzenie ich dla różnych nachyleń ściany. Poniżej dla przykładu przedstawiono wykres sprawności ładowania (rys. 9) w funkcji współczynnika wypełnienia organu i prędkości posuwu. Wykres przedstawiony na rysunku 9 wyraźnie wskazuje, że wraz ze wzrostem prędkości posuwu $v_{p}$, gdy organ uzyskuje coraz większe wypełnienie, następuje zdecydowane zmniejszenie sprawności ładowania. Podobne zależności otrzymano w przypadku pozostałych nachyleń stanowiska (ściany), czego przykładem jest rysunek 10 . Na wykresie przedstawionym na rysunku 10 również widać, że przy pochyleniu ściany $9^{\circ}$ i dla większych prędkości posuwu zwiększa się współczynnik wypełnienia organu, a tym samym znacząco zmniejsza się sprawność ładowania.

\section{Ustawienie wyrobiska (ściany) poziome}

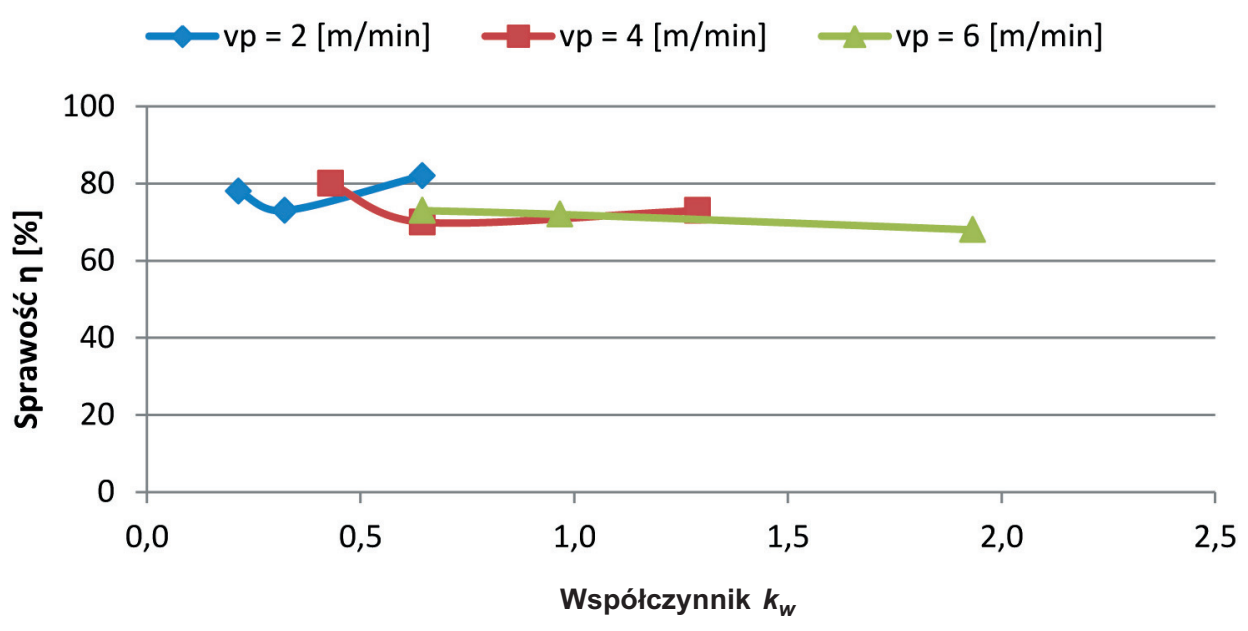

Rys. 8. Sprawność ładowania $\eta_{t} w$ funkcji wspótczynnika wypetnienia organu $k_{w}$. dla różnych prędkości posuwu $v_{p}$ dla ściany poziomej 
Tabela 2

Wyniki badań dla różnych parametrów kinematycznych nastawianych podczas realizacji badań

\begin{tabular}{|c|c|c|c|c|c|c|c|c|c|c|}
\hline $\mathbf{L p}$. & $\begin{array}{c}\boldsymbol{v}_{\boldsymbol{p}} \\
{[\mathbf{m} / \mathbf{m i n}]}\end{array}$ & $\begin{array}{c}\boldsymbol{n} \\
{[\mathbf{o b r} / \mathbf{m i n}]}\end{array}$ & $\boldsymbol{k}_{\boldsymbol{w}}$ & $\begin{array}{c}\boldsymbol{a} \\
{[\mathbf{m m}]}\end{array}$ & $\begin{array}{c}\boldsymbol{b} \\
{[\mathbf{m m}]}\end{array}$ & $\begin{array}{c}\boldsymbol{h} \\
{[\mathbf{m m}]}\end{array}$ & $\begin{array}{c}\boldsymbol{h}_{\mathbf{1}} \\
{[\mathbf{m m}]}\end{array}$ & $\begin{array}{c}\boldsymbol{P}_{\boldsymbol{c}} \\
{\left[\mathbf{c m}^{2}\right]}\end{array}$ & $\begin{array}{c}\boldsymbol{P}_{\boldsymbol{z}_{2}} \\
{\left[\mathbf{c m}^{2}\right]}\end{array}$ & $\begin{array}{c}\boldsymbol{\eta} \\
{[\mathbf{\%}]}\end{array}$ \\
\hline 1 & 2 & 40 & 0,644 & 48 & 24,2 & 15 & 9 & 357 & 292 & 82 \\
\hline 2 & 2 & 80 & 0,322 & 42,3 & 18,6 & 19 & 15 & 396 & 290 & 73 \\
\hline 3 & 2 & 120 & 0,215 & 45,8 & 21,1 & 18 & 12 & 407 & 319 & 78 \\
\hline 4 & 4 & 40 & 1,288 & 42,2 & 18,5 & 14 & 11 & 306 & 223 & 73 \\
\hline 5 & 4 & 80 & 0,644 & 41,1 & 17,1 & 14 & 12 & 294 & 206 & 70 \\
\hline 6 & 4 & 120 & 0,429 & 46,5 & 22,2 & 11 & 8 & 267 & 213 & 80 \\
\hline 7 & 6 & 40 & 1,933 & 39,2 & 17 & 15 & 13 & 301 & 206 & 68 \\
\hline 8 & 6 & 80 & 0,966 & 41,7 & 18,2 & 14 & 11 & 290 & 210 & 72 \\
\hline 9 & 6 & 120 & 0,644 & 43 & 17,9 & 14 & 12 & 307 & 223 & 73 \\
\hline
\end{tabular}

\section{Nachylenie ściany $3^{\circ}$}

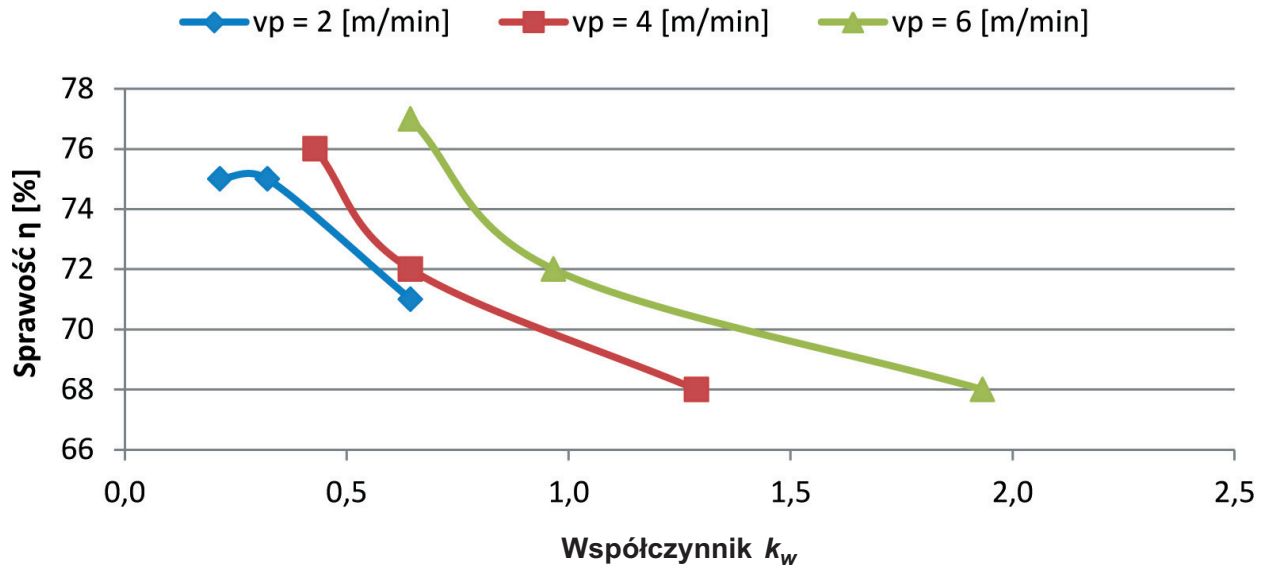

Rys. 9. Sprawność ładowania $\eta_{t} w$ funkcji wspótczynnika wypetnienia organu $k_{w}$ dla różnych prędkości posuwu $v_{p}$ przy nachyleniu ściany $3^{\circ}$

\section{Nachylenie ściany $9^{\circ}$}

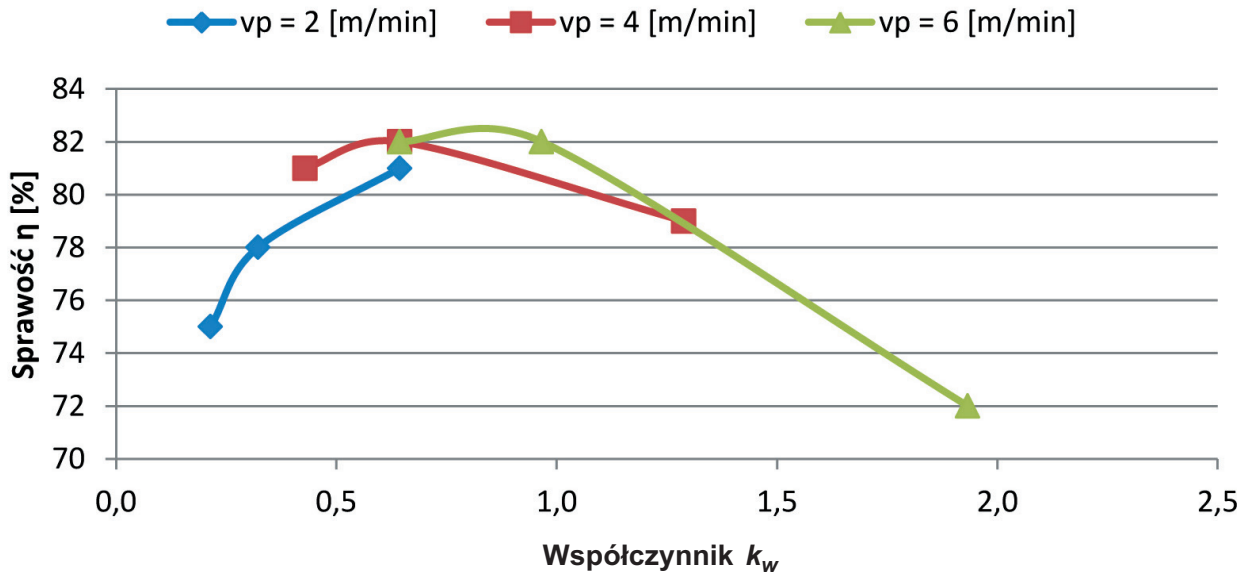

Rys. 10. Sprawność ładowania $\eta_{t} w$ funkcji współczynnika wypetnienia organu $k_{w}$ dla różnych prędkości posuwu $v_{p}$ przy nachyleniu ściany $9^{\circ}$ 


\section{PODSUMOWANIE}

Przeprowadzone badania, jak już wspomniano, należy uznać za badania pilotażowe w temacie ładowania urobku ślimakowymi organami dla nachylonych wyrobisk. Badania laboratoryjne i późniejsza analiza ich wyników pozwoliły na sprecyzowanie wniosków i wskazań co do dalszych prób (badań) w tym temacie. Głównym wnioskiem wynikającym z badań jest to, że nachylenie wyrobiska ma wpływ na proces ładowania, gdyż wraz ze wzrostem nachylenia sprawność ładowania organem bez ładowarki nieznacznie spada. Wszystkie próby eksperymentu były przeprowadzone dla zasymulowania kombajnu poruszającego się po wzniosie. Badania również wskazują na to, że wraz ze wzrostem prędkości posuwu i kąta nachylenia ściany rośnie wypełnienie organu, a tym samym ma to wpływ na sprawność ładowania.

Badania te były pierwszymi badaniami procesu ładowania przy nachyleniu podłużnym ściany w Katedrze Maszyn Górniczych, Przeróbczych i Transportowych AGH. Wcześniej były przeprowadzane tylko badania dla ścian poziomych. W związku z powyższym badania powinny być kontynuowane dla nachylenia podłużnego stanowiska dla większych kątów oraz dla organów z ładowarkami osłonowymi. Być może dla większych nachyleń ściany i przy zastosowaniu ładowarki osłonowej będzie widoczny podczas badań wzrost mocy na silniku organu i posuwu. Proponuje się również wprowadzenie układu odbioru urobku na stanowisku, co lepiej obrazowałoby proces ładowania.

\section{Literatura}

[1] Szlązak N., Szlązak J.: Wentylacja wyrobisk ścianowych w kopalniach węgla kamiennego, $w$ warunkach zagrożen metanowego i pożarowego, „Górnictwo i Geologia” 2013, 8, 2: 115-131.

[2] Borówka B.: Próba oceny technicznych możliwości eksploatacji zasobów pozabilansowych $w$ kopalni węla kamiennego, „Górnictwo i Geoinżynieria” 2010, 34, 3: 169-185.
[3] Jaszczuk M.: Ścianowe systemy mechanizacyjne, Wydawnictwo Naukowe „Ślask”, Katowice 2007.

[4] Krauze K.: Urabianie skat kombajnami ścianowymi, Wydawnictwo Naukowe „Śląsk”, Katowice 2000.

[5] Bołoz Ł.: Maszyny urabiające $w$ ścianowych systemach eksploatacji cienkich pokładów węla kamiennego, „Systemy Wspomagania w Inżynierii Produkcji. Górnictwo - Perspektywy i Zagrożenia: Węgiel, Tania Czysta Energia i Miejsca Pracy" 2018, 7, 1: 143-154.

[6] Bołoz Ł.: Longwall shearers for exploiting thin coal seams as well as thin and highly inclined coal seams, ,Mining - Informatics, Automation and Electrical Engineering" 2018, 2: 59-72.

[7] Korski J., Bednarz R.: Kombajnowy system ścianowy jako efektywna alternatywa dla strugów weglowych, „Mechanizacja i Automatyzacja Górnictwa” 2012, 50, 9: 31-38.

[8] Krauze K., Wydro T., Bołoz Ł.: Problemy zwiąane z procesem ładowania frezującymi organami ślimakowymi, w: Problemy bezpieczeństwa $w$ budowie i eksploatacji maszyn $i$ urządzeń górnictwa podziemnego. Monografia, red. K. Krauze, Lędziny 2010: 124-133.

[9] Krauze K., Wydro T.: Badania laboratoryjne procesu tadowania frezujacymi organami ślimakowymi, w: Innowacyjne techniki i technologie dla górnictwa. Monografia, red. nauk. A. Klich, A. Kozieł, Instytut Techniki Górniczej KOMAG, Gliwice 2010: 387-404.

[10] Hamala K., Wydro T.: Stanowisko do badań procesu ładowania frezującym organem ślimakowym, „Maszyny Górnicze” 2005, 1: 17-21.

[11] Wydro T.: Badania laboratoryjne procesu ładowania frezujacymi organami ślimakowymi przy różnym stopniu ich wypetnienia i granulacji urobku, AGH Akademia Górniczo-Hutnicza im. Stanisława Staszica w Krakowie, Kraków 2011 [praca doktorska].

[12] Jaszczuk M.: Kombajnowe systemy mechanizacyjne, „Skrypty Uczelniane" nr 1224, Gliwice 1986.

[13] Krauze K., Wydro T.: Analiza wyników badań procesu tadowania frezujacymi organami ślimakowymi, w: Zagadnienia mechaniki pękania i skrawania materiałów. Monografia, red. J. Jonak, Lubelskie Towarzystwo Naukowe, Lublin 2010: 140-156.

[14] Krysicki W. et al.: Rachunek prawdopodobieństwa i statystyka matematyczna w zadaniach. Część 2, Wydawnictwo Naukowe PWN, Warszawa 1999.

dr inż. TOMASZ WYDRO

Katedra Maszyn Górniczych, Przeróbczych i Transportowych

Wydziat Inżynierii Mechanicznej i Robotyki AGH Akademia Górniczo-Hutnicza im. St. Staszica w Krakowie al. Mickiewicza 30, 30-059 Kraków wydro@agh.edu.pl 